\title{
RESPON PETANI DALAM PEMANFAATAN LIMBAH ORGANIK SAYUR SEBAGAI PUPUK KOMPOS PADA KOMODITAS SAYURAN DI DESA CIKIDANG KECAMATAN LEMBANG KABUPATEN BANDUNG BARAT
}

\author{
Riyyan Insani ${ }^{1}$, Dwiwanti Sulistyowati ${ }^{2}$, Wida Pradiana ${ }^{3}$ \\ ${ }^{1}$ Politeknik Pembangunan Pertanian Bogor, email: riyyaninsani0@gmail.com \\ ${ }^{2}$ Politeknik Pembangunan Pertanian Bogor
}

\begin{abstract}
Abstrak
Jawa Barat merupakan salah satu daerah penghasil sayuran dan buah-buahan semusim. Salah satu daerah penghasil komoditas sayuran terbesar di Jawa Barat adalah Kabupaten Bandung Barat, khususnya di Desa Cikidang Kecamatan Lembang. Dalam budidaya sayuran akan menghasilkan limbah seperti gulma hasil sanitasi lahan ataupun limbah sisa panen. Biasanya limbah tersebut dibiarkan tanpa ada perlakuan khusus. Hal ini disebabkan oleh rendahnya respon petani untuk memanfaatkan limbah tersebut. Penelitian ini bertujuan untuk mendeskripsikan, menganalisis indikator yang berhubungan, dan menganalisis indikator apa yang harus ditingkatkan untuk memacu respon petani dalam pemanfaatan limbah organik sayur sebagai pupuk kompos. Penelitian ini dilaksanakan dari bulan Maret sampai bulan Juli 2020 di Desa Cikidang, Kecamatan Lembang, Kabupaten Bandung Barat. Sampel penelitian ini berjumlah 30 orang menggunakan quota sampling. Variabel penelitian terdiri dari karakteristik individu, faktor eksternal dan respon petani. Teknik analisis data yang digunakan adalah analisis deskriptif, korelasi rank spearman, dan Kendall's $W$. Hasil penelitian menunjukkan bahwa respon petani termasuk kedalam kategori sedang. Indikator yang berhubungan nyata adalah tingkat pendidikan formal, lama berusahatani, dan kegiatan penyuluhan. Indikator yang harus ditingkatkan adalah keterampilan petani. Pada penelitian selanjutnya, diharapkan dapat mengkaji variabel dan indikator baru agar lebih baik dari penelitian ini.
\end{abstract}

Kata Kunci : Respon, Limbah Sayuran, Pupuk Kompos, Sayuran, Penyuluhan Pertanian

\section{Abstract}

West Java is one of the biggest areas of vegetable and fruit production. One of biggest production area in West Java at West Bandung district, especially at Cikidang Village, Lembang. In the cultivation of vegetables will produce waste such as weeds from land sanitation or crop residual waste. Usually the waste is left without any special treatment. Purpose of this research are to describe, analyze related indicator and make interesting strategic to farmer for utilize their waste being compost fertilize from related indicator. This research held at Cikidang Village, Lembang, West Bandung from March - July 2020 with 30 farmers as sample by using quota sampling. The research variable consisted of farmer character, external factor and farmers respond. The method of this research is description, spearman rank correlation and Kendall's $W$ technic to analyze data of research. Result of the research at farmers respond in this research at medium category and related significant indicator are level of formal education, length of work, and extension activities. Strategy to interesting farmer are increasing farmers skill. The suggestion from this research is able to study new variables and indicators to be better than this research.

Keywords: Response, Vegetable Waste, Compost Fertilizer, Vegetables, Agriculture Extension 


\section{Pendahuluan}

Tanaman hortikultura merupakan salah satu tanaman yang menunjang pemenuhan gizi mayarakat sebagai sumber vitamin, mineral, protein, dan karbohidrat. Salah satu produk hortikultura yang memiliki potensi pasar ekspor yang besar adalah sayuran. Menurut data yang diperoleh dari Badan Pusat Statistik (BPS) Indonesia (2018), Indonesia mengekspor tujuh belas jenis sayuran semusim, yaitu bawang merah, bawang putih, kacang merah, kembang kol, kentang, kubis, lobak, wortel, bayam, buncis, cabai besar, jamur, kacang panjang, ketimun, labu siam, terung, dan tomat. Total nilai ekspor sayuran semusim tahun 2018 mencapai 11,82 juta US \$.

Jawa Barat merupakan salah satu daerah penghasil sayuran dan buahbuahan semusim. Salah satu daerah penghasil komoditas sayuran terbesar di Jawa Barat adalah Kabupaten Bandung Barat, khususnya di Kecamatan Lembang. Hampir seluruh petani membudidayakan sayuran pada lahan yang mereka miliki. Di tahun 2018, Luas panen komoditas sayuran di Kecamatan Lembang mencapai $2.479 \mathrm{Ha}$ dengan total produksi sebanyak 650.052 kuintal yang terdiri dari 16 jenis sayuran yang dibudidayakan (BPS Indonesia, 2019).

Dalam budidaya sayuran akan menghasilkan limbah seperti gulma hasil sanitasi lahan ataupun limbah sisa panen. Seperti pada sayuran daun, ketika waktunya panen biasanya daun tua dikupas dan dibuang karena fisiknya yang rusak dan kotor juga memiliki rasa yang pahit. Biasanya petani membuangnya langsung di lahan atau mengupasnya saat di rumah kemasan. Biasanya limbah tersebut dibiarkan begitu saja tanpa ada perlakuan khusus dari petani. Seperti dilaporkan oleh Rinanto et al., (2015) yang mengungkapkan bahwa masalah yang muncul di lahan petani adalah banyaknya sisa hasil panen seperti daun dan batang tanaman yang tidak termanfaatkan. Petani kebanyakan membiarkan limbah tersebut membusuk di kebun. Padahal limbah sayur tersebut dapat menjadi pupuk organik jika dikelola dengan baik dengan perlakuan tertentu. Ketika diwawancarai, petani menyebutkan bahwa lebih baik membeli pupuk yang sudah jadi daripada membuatnya sendiri. Hal ini disebabkan oleh rendahnya respon petani untuk memanfaatkan limbah organik dari sayur tersebut. Limbah organik merupakan jenis sampah yang mudah membusuk dan berpotensi mencemari lingkungan dan kesehatan masyarakat Salah satu cara untuk mengelola limbah organik sayur tersebut adalah dengan mengolahnya menjadi pupuk kompos agar limbah dapat diminimalisir dan lingkungan menjadi lebih bersih dan sehat (Wahyono, 2011). Berdasarkan permasalahan diatas, maka perlu adanya pengkajian terkait respon petani dalam pemanfaatan limbah organik sayur sebagai pupuk kompos pada komoditas sayuran. 
Adapun tujuan dari penelitian ini adalah mendeskripsikan respon petani, menganalisis indikatorindikator yang berhubungan dengan respon petani, dan menganalisis indikator apa yang perlu ditingkatkan untuk memacu respon petani dalam pemanfaatan limbah organik sayur sebagai pupuk kompos.

\section{Metode Penelitian}

Penelitian dilaksanakan di Desa Cikidang, Kecamatan Lembang, Kabupaten Bandung Barat mulai bulan Maret sampai Juli 2020. Kriteria penentuan populasi secara umum dalam kegiatan kajian ini adalah semua petani di Desa Cikidang yang melaksanakan budidaya tanaman sayuran dan tergabung dalam poktan. Karena adanya keterbatasan waktu, tenaga, biaya juga dikarenakan kegiatan ini dilaksanakan di tengah pandemi COVID-19, sehingga diputuskan bahwa petani yang akan dijadikan populasi hanya diambil dari dua kelompoktani aktif yang pernah melaksanakan pembuatan pupuk kompos sejumlah 50 responden (Balai Penyuluhan Pertanian Kecamatan Lembang, 2018). Selanjutnya dilakukan pengambilan sampel menggunakan quota sampling. Jumlah kuota sampel yang ditentukan oleh pengkaji adalah sejumlah 30 responden, yang terdiri dari 15 petani dari Poktan Tauhid dan 15 petani dari Poktan Motekar dengan karakteristik kontrol yaitu anggota aktif, sedang atau pernah menggunakan pupuk kompos, dan pernah membuat pupuk kompos. Variabel penelitian terdiri dari karakteristik individu (X1), faktor eksternal (X2) dan respon petani (Y).

Instrumen penelitian menggunakan kuesioner terbuka pada X1 dan kuesioner tertutup pada X2 dan Y. Selanjutnya kuesioner diolah menggunakan perangkat lunak Microsoft Excel 2019. Pada kuesioner kuesioner ini, uji validitas dilakukan menggunakan formula korelasi Product Moment dari Karl Person. Dari hasil uji validitas, jumlah total keseluruhan soal yang valid adalah 50 butir dan 30 butir soal tidak valid. Selanjutnya dilakukan uji reliabilitas menggunakan Microsoft Excel 2019 dengan formula korelasi Cronbach Alfa. Berdasarkan hasil uji reliabilitas, nilai reliabilitas masing masing variabel mendapatkan nilai sangat kuat, yaitu 0,91 dan 0,94. Artinya, instrumen dapat dipercaya dan jika digunakan berulang kali pada objek yang sama, maka akan mendapatkan hasil yang sama pula.

Data dikumpulkan menggunakan teknik observasi, kuesioner, wawancara, dan studi pustaka. Analisis data yang digunakan adalah analisis deskriptif yang dikategorikan kedalam 3 kategori, yaitu, rendah, sedang, dan tinggi. Selanjutnya hubungan indikator dengan respon petani dianalisis menggunakan analisis korelasi rank spearman. Terakhir, indikator yang harus ditingkatkan dianalisis menggunakan analisis Kendall's $W$. 
Hasil dan Pembahasan

\section{Karakteristik Individu}

Karakteristik individu yang dikaji dalam penelitian ini adalah umur, lama pendidikan formal, lama berusahatani, dan luas lahan garapan (Tabel 1).

Tabel 1

\section{Karakteristik Individu}

\begin{tabular}{cccc}
\hline $\begin{array}{c}\text { Karak- } \\
\text { teristik }\end{array}$ & Kategori & f & $\%$ \\
\hline Umur & $0-14$ & - & - \\
(tahun) & $15-63$ & 27 & 90 \\
& $>63$ & 3 & 10 \\
\hline Rata-Rata & 41,27 tahun & & \\
\hline Tingkat & SD & 18 & 60 \\
Pendidikan & SLTP & 4 & 13,3 \\
Formal & SLTA & 2 & 6,7 \\
& PT & 6 & 20 \\
\hline Modus & SD & & \\
\hline Lama & $<10$ & 5 & 16,7 \\
Berusaha- & $10-20$ & 15 & 50 \\
Tani (tahun) & $>20$ & 10 & 33,3 \\
\hline Rata-rata & 20,4 tahun & \\
\hline Luas Lahan & $<1000$ & 0 & 0 \\
Garapan & $1000-2000$ & 5 & 16,7 \\
(m ${ }^{2}$ ) & $>2000$ & 25 & 83,3 \\
\hline Rata-rata & $4663,3 \mathrm{~m}^{2}$ \\
\hline Sumber: Data & &
\end{tabular}

Sumber: Data diolah Penulis (2020)

Umur petani di Desa Cikidang bervariasi dengan rata-rata umur adalah 41,27 tahun. Menurut Badan Pusat Statistika (2016) umur 41,27 tahun termasuk kedalam umur yang produktif. Adapun umur responden keseluruhan terdiri dari 27 orang produktif $(90 \%)$ dan 3 orang tidak produktif $(10 \%)$. Pada umur produktif, responden dianggap sudah mampu menghasilkan barang dan jasa dalam proses produksi, terutama di bidang pertanian. Selain itu, pada umur produktif petani memiliki kemampuan fisik yang baik untuk melakukan kegiatan usahatani. Hal ini selaras dengan pernyataan Manatar et al., (2017) yang mengatakan bahwa jika ditinjau dari segi fisik, semakin tua umur seseorang setelah melewati batas umur tertentu, maka semakin berkurang kemampuan untuk bekerja. Namun, petani dengan umur yang tidak produktif bukan berarti sudah tidak mampu menghasilkan barang dan jasa. Berdasarkan temuan di lapangan, petani yang sudah tidak produktif masih tetap melakukan aktivitas usaha tani seperti biasa, namun waktu pengerjaan dan hasil kerja terbatas dengan kemampuan fisik yang dimiliki oleh petani tersebut.

Tingkat pendidikan formal petani dibagi menjadi empat kategori, yaitu SD/Sederajat, SMP/Sederajat, SMA/Sederajat, dan Perguruan Tinggi. Berdasarkan tabel 15, mayoritas petani responden hanya memiliki pendidikan formal sampai SD atau sederajat, yaitu sejumlah 18 orang. Adapun sejumlah 4 responden memiliki pendidikan formal sampai SMP, 2 orang responden SMA, dan 4 orang responden telah menempuh pendidikan di perguruan tinggi. Hasil ini selaras dengan penelitian Wardana et al., (2017), Manyamsari \& Mujiburrahmad, (2014), dan Alam, (2010) yang menyatakan bahwa tingkat pendidikan formal petani mayoritas masih rendah, yaitu hanya sampai SD. Hal ini menunjukkan mayoritas petani di lokasi penelitian masih belum memiliki kesadaran akan pentingnya pendidikan. Hal ini selaras dengan penelitian Putri et al., (2019) yang menyatakan bahwa tingkat pendidikan formal petani sebagian besar adalah Sekolah Dasar (SD) yang disebabkan karena kondisi ekonomi dan kesadaran untuk menempuh pendidikan masih rendah.

Tingkat pendidikan seseorang berhubungan dengan kepribadian dan perilaku orang tersebut. Menurut Soekartiwi dalam Heriyadi et al., (2016), tingkat pendidikan akan mempengaruhi cara berpikir seseorang yaitu cara memandang 
permasalahan, cara menyelesaikan permasalahan dan cara berinteraksi dengan orang lain serta dapat mempengaruhi petani dalam mempertimbangkan keputusan dalam penerapan teknologi usahatani. Semakin lama seseorang mengenyam pendidikan, akan semakin rasional

Menurut Manyamsari \& Mujiburrahmad (2014) Lama berusaha tani dikategorikan menjadi 3 , yaitu pengalaman baru (kurang dari 10 tahun), pengalaman sedang (10-20 tahun) dan pengalaman lama (lebih dari 20 tahun). Lama responden dalam berusahatani cukup bervariasi. Pada tabel 14 menunjukkan bahwa sebagian besar petani $(50 \%)$ yaitu 15 petani responden memiliki pengalaman berusahatani sedang, yaitu antara $10-20$ tahun. Sedangkan 5 responden $(16,7 \%)$ memiliki pengalaman baru dan 10 responden $(33,3 \%)$ memiliki pengalaman lama. Temuan di lapangan menunjukkan bahwa semakin lama pengalaman bertani, maka penerapan teknologi baru akan mengalami perlambatan. Hal ini karena petani yang sudah memilki pengalaman bertahun-tahun sudah terbiasa dengan teknologi konvensional yang mereka terapkan dari musim ke musim, sehingga mereka akan ragu terhadap teknologi baru.

Anggini et al., (2019) menyatakan bahwa pengalaman yang dimiliki seseorang menjadi referensi dalam mengambil suatu keputusan pada setiap tindakannya. Hal ini selaras dengan bukti di lapangan bahwa semakin lama pengalaman bertani petani, mereka menjadi menimbangnimbang inovasi baru yang bermunculan, apakah inovasi tersebut akan meningkatkan produktivitas atau malah sebaliknya. Selain itu, Rukka et al., (2013) juga mengungkapkan bahwa pengalaman petani dalam berusahatani berhubungan dengan cara mengadopsi suatu inovasi. Semakin lama pengalaman berusahatani maka tingkat mengadopsi suatu teknologi akan semakin tinggi.

Sebanyak 25 orang responden $(83,3$ $\%)$ memiliki lahan usahatani yang luas, sedangkan 5 orang responden $(16,7 \%)$ memiliki lahan usahatani yang sedang. Selaras dengan penelitian Wardana et al., (2017) dan Manatar et al., (2017) yang mengatakan bahwa rata-rata luas lahan yang dimiliki oleh petani termasuk kedalam kategori luas. Berdasarkan temuan di lapangan, petani yang memiliki lahan tidak luas biasanya mudah menerapkan teknologi baru, hal ini karena petani cukup memiliki waktu untuk mencoba hal baru karena lahannya tidak luas sehingga petani tidak terlalu takut rugi jika hasilnya mengecewakan.

\section{Faktor Eksternal}

Indikator yang dianalisis dalam faktor eksternal adalah kegiatan penyuluhan, ketersediaan sarana dan prasarana, akses informasi, dan dukungan kelompoktani. Adapun hasil analisis dapat dilihat pada Tabel 2.

\section{Tabel 2}

Faktor Eksternal

\begin{tabular}{ccccc}
\hline $\begin{array}{c}\text { Indi- } \\
\text { kator }\end{array}$ & $\begin{array}{c}\text { Kate- } \\
\text { gori }\end{array}$ & $\begin{array}{c}\text { Krite- } \\
\text { ria }\end{array}$ & f & $\%$ \\
\hline Kegia- & $7-14$ & Rendah & 12 & 40 \\
tan & $15-21$ & Sedang & 18 & 60 \\
Penyu- & $22-28$ & Tinggi & 0 & 0 \\
luhan & & & & \\
\hline Keter- & $6-12$ & Rendah & 8 & 26,7 \\
sediaan & $13-18$ & Sedang & 19 & 63,3 \\
Sapras & $19-24$ & Tinggi & 3 & 10 \\
\hline Akses & $5-10$ & Rendah & 3 & 10 \\
Infor- & $11-15$ & Sedang & 24 & 80 \\
masi & $16-20$ & Tinggi & 3 & 10 \\
\hline
\end{tabular}




\begin{tabular}{ccccc}
\hline Duku- & $3-6$ & Rendah & 7 & 23,3 \\
ngan & $7-9$ & Sedang & 5 & 16,7 \\
Poktan & $10-12$ & Tinggi & 18 & 60 \\
\hline
\end{tabular}

Sumber: Data diolah Penulis (2020)

Pada indikator kegiatan penyuluhan, jumlah responden yang mendapatkan skor rendah adalah 12 responden $(40 \%)$ dan 18 (60\%) responden berada pada kategori sedang. Berdasarkan data diatas, mayoritas responden menilai tingkat kegiatan penyuluhan di lokasi penelitian adalah sedang. Hasil ini sejalan dengan Putri et al., (2019) yang mengatakan bahwa kegiatan penyuluhan di kelompoktani sudah cukup berjalan dengan baik. Berdasarkan wawancara di lapangan, kegiatan penyuluhan di Desa Cikidang sudah jarang dilakukan secara berkelompok, namun penyuluh melakukan pendekatan perorangan. Kegiatan penyuluhan di Desa Cikidang juga tidak dilaksanakan secara rutin baik seminggu sekali ataupun sebulan sekali. Biasanya kegiatan penyuluhan hanya dilakukan ketika ada program dari pemerintah saja. Selain itu, partisipasi petani dalam penyuluhan juga tergolong rendah. Hal ini disebabkan oleh kesibukan masing-masing anggota poktan dan kurangnya kesadaran dari petani. Fakta ini selaras dengan penelitian Putri et al., (2019) yang mengatakan bahwa kegiatan penyuluhan kurang terorganisasi dengan baik yang disebabkan oleh kesibukan para anggota dan kurangnya partisipasi anggota. Namun, penyuluh tetap aktif memberikan ilmu kepada petani meskipun secara non-formal, seperti sambil berbincang - bincang di rumah petani ataupun di kebun milik petani.

Selanjutnya, Sebanyak 8 responden $(26,7 \%)$ memberikan jawaban rendah, 19 responden $(63,3 \%)$ memberikan jawaban sedang dan 3 responden $(10 \%)$ memberikan jawaban tinggi. Selaras dengan penelitian Alam, (2010) yang menyatakan bahwa penilaian petani responden terhadap dukungan sarana produksi mayoritas termasuk dalam kategori sedang atau cukup tersedia. Berdasarkan temuan di lapangan, Desa Cikidang memiliki rumah pengomposan yang dikelola oleh Gapoktan di desa tersebut. Adanya rumah pengomposan direspon cukup baik oleh petani setempat. Namun kegiatan membuat kompos di tempat tersebut hanya berjalan sekitar 1 tahun. Hal ini disebabkan rumah kompos terletak di ujung desa, sehingga petani di bagian desa yang lain tidak mudah untuk mengaksesnya. Selain itu, terhentinya kegiatan membuat pupuk kompos di Desa Cikidang disebabkan kesulitan mendapatkan bahan baku. Untuk bahan seperti limbah sayuran sangat melimpah dan mudah didapatkan di sekitar kebun petani, namun kotoran ternak harus didapatkan dari desa lain, dikarenakan populasi ternak di Desa Cikidang hanya sedikit dan itu pun jauh dari rumah kompos. Pada akhirnya, petani hanya melakukan pengomposan secara alami tanpa dibubuhi pengolahan lebih lanjut. hal ini selaras dengan penelitian Viaene et al., (2016) yang mengungkapkan bahwa untuk memenuhi kebutuhan biomassa dalam pembuatan pupuk kompos, petani harus mendapatkannya dari pihak eksternal/pihak ketiga sehingga menyebabkan pembuatan pupuk kompos menjadi lebih mahal.

Berdasarkan hasil perhitungan pada indikator akses informasi, terdapat 3 responden $(10 \%)$ yang termasuk ke dalam kategori rendah, 24 responden $(80 \%)$ termasuk ke dalam kategori 
sedang, dan 3 responden $(10 \%)$ termasuk ke dalam kategori yang dilakukan oleh petani mendapatkan skor sedang $(12,8)$. Sebagian besar informasi yang didapatkan oleh responden berasal dari penyuluh dan petani lain. Hanya sedikit petani yang mengakses informasi dari internet. Hal ini dikarenakan petani hanya menggunakan smartphone untuk keperluan komunikasi sehari-hari saja. Selain itu, informasi dari BPP juga hanya sebagian petani yang dapat mengaksesnya. Hal ini karena biasanya petani yang berkunjung ke BPP adalah ketua poktan dan juga petani yang memiliki keperluan pribadi. Jarang sekali ada petani yang sengaja mendatangi BPP hanya untuk mencari informasi seputar pupuk kompos. Namun temuan di lapangan menunjukkan bahwa penyebaran informasi dari petani ke petani lain terjadi lebih cepat. Hal ini karena petani akan lebih percaya terhadap suatu teknologi baru jika ada petani yang sudah menerapkannya terlebih dahulu dan hasil dari teknologi tersebut memuaskan. Dari sini petani mulai menggali informasi kepada petani yang sudah menerapkan teknologi tersebut.

Selain dari petani lain, sumber informasi lain yang dimanfaatkan oleh petani adalah leaflet/folder/brosur yang diberikan oleh penyuluh ketika kegiatan penyuluhan ataupun kunjungan. Media ini adalah media yang sering digunakan oleh para penyuluh di Kecamatan Lembang. Seperti hasil penelitian Ruyadi et al., (2017) yang menyampaikan bahwa media komunikasi dan informasi yang banyak dimanfaatkan para penyuluh yang ada di tiga lokasi yakni Lembang, Purwakarta dan Kabupaten Sumedang yaitu media brosur dan leaflet. Adapun mengenai frekuensi pemanfaatan media brosur dan leaflet ini yaitu sekitar 5 kali dalam tiga bulan terakhir. Sedangkan berkaitan dengan intensitas pemanfaatannya dalam setiap kali menggunakan media brosur dan leaflet tersebut yaitu sekitar 1-2 jam.

Selanjutnya, pada indikator dukungan kelompoktani, sebanyak 7 responden $(23,3 \%)$ termasuk ke dalam kategori rendah, 5 responden $(16,7 \%)$ termasuk ke dalam kategori sedang, dan 18 responden $(60 \%)$ termasuk ke dalam kategori tinggi, sama seperti yang disampaikan oleh Alam, (2010), bahwa penilaian petani responden terhadap dukungan kelompoktani umumnya tergolong tinggi. Kelompoktani mendukung kegiatan pembuatan pupuk kompos. Bahkan terdapat struktur organisasi khusus untuk mengelola kegiatan pembuatan pupuk kompos. Namun seiring berjalannya waktu, dikarenakan pengurus tersebut juga petani yang harus mengelola usahataninya sendiri, kegiatan pengomposan pun perlahan padam. Berdasarkan hasil wawancara di lapangan, petani mengungkapkan bahwa kegiatan mengelola pupuk kompos adalah kegiatan yang bersifat sukarela, sehingga petani pun lebih mengutamakan kegiatannya di lahan masing-masing.

\section{Respon Petani}

Respon petani dikategorikan kedalam 3 kategori, yaitu rendah, sedang dan tinggi. Adapun masing-masing frekuensi responden berdasarkan rentang kategori tersebut dapat dilihat pada Tabel 3

\section{Tabel 3}

Respon Petani

\begin{tabular}{cccc}
\hline Kategori & Keterangan & f & \% \\
\hline $29-58$ & Rendah & 11 & 36,7 \\
$59-87$ & Sedang & 16 & 53,3
\end{tabular}




\begin{tabular}{rrrr}
$88-116 \quad$ Tinggi & 3 & 10 \\
\hline Total & $\mathbf{3 0}$ & $\mathbf{1 0 0}$ \\
\hline
\end{tabular}

Sumber: Data diolah Penulis (2020)

Melihat tabel diatas, dapat dikatakan bahwa sebagian besar respon petani termasuk kedalam kategori sedang dengan frekuensi 16 responden $(53,3 \%)$. Adapun 11 responden $(36,7 \%)$ termasuk kedalam kategori rendah, dan 3 responden (10\%) termasuk ke dalam kategori tinggi. Hasil ini lebih baik dari penelitian sebelumnya yang mengungkapkan bahwa perilaku petani yang meliputi pengetahuan, sikap, dan keterampilan dalam pemanfaatan limbah sayuran termasuk kedalam kategori rendah dengan persentase 58,3\% (Anggini et al., 2019). Perbedaan yang terjadi dapat disebabkan perbedaan sampel penelitian dan lokasi penelitian. Berdasarkan temuan di lapangan, petani cukup mengetahui tentang manfaat dari limbah sayuran, namun petani enggan memanfaatkannya sebagai pupuk kompos karena biaya angkut bahan yang tidak sedikit dan posisi rumah pengomposan yang berada di ujung desa, sehingga mereka pun hanya membiarkannya membusuk secara alami di lapangan. Selain itu, kemampuan petani dalam membuat pupuk kompos juga berkurang karena jarangnya petani membuat pupuk kompos sendiri dan mereka cenderung menggunakan pupuk kandang ayam sebagai pupuk dasar dan pupuk kimia sebagai pupuk susulan. Hal ini selaras dengan penelitian (Viaene et al., 2016) yang mengatakan bahwa hanya sebagian kecil petani yang menggunakan pupuk kompos di lahan budidaya yang mereka miliki.

Adapun tingkat respon petani juga dianalisis berdasarkan indikatorindikator variabel. Indikator respon petani yang dianalisis dalam penelitian ini adalah pengetahuan, sikap dan keterampilan (Tabel 4).

\section{Tabel 4}

Distribusi Indikator Respon

\begin{tabular}{ccccc}
\hline $\begin{array}{c}\text { Indi- } \\
\text { kator }\end{array}$ & $\begin{array}{c}\text { Kate- } \\
\text { gori }\end{array}$ & $\begin{array}{c}\text { Kri- } \\
\text { teria }\end{array}$ & $\mathbf{f}$ & $\%$ \\
\hline Penge- & $9-18$ & Rendah & 11 & 36,7 \\
tahuan & $19-27$ & Sedang & 12 & 40 \\
& $28-36$ & Tinggi & 7 & 23,3 \\
\hline \multirow{2}{*}{ Sikap } & $13-26$ & Rendah & 11 & 36,7 \\
& $27-39$ & Sedang & 19 & 633 \\
& $40-52$ & Tinggi & 0 & 10 \\
\hline \multirow{2}{*}{ Kete- } & $7-14$ & Rendah & 16 & 53,3 \\
rampilan & $15-21$ & Sedang & 10 & 33,3 \\
& $22-28$ & Tinggi & 4 & 13,3 \\
\hline Sumber: Data diolah
\end{tabular}

Sumber: Data diolah Penulis (2020)

Pada indikator pengetahuan, distribusi frekuensi nya adalah sebanyak 11 responden $(36,7 \%)$ termasuk ke dalam rendah, 12 responden $(40 \%)$ sedang, dan 7 responden $(23,3 \%)$ tinggi. Hasil ini selaras dengan penelitian Anggini et al., (2019) yang mengungkapkan bahwa tingkat pengetahuan petani dalam pemanfaatan limbah sayuran sebagai pupuk bokashi atau kompos sebagian besar tergolong sedang dengan persentase $51,7 \%$. Petani belum menyadari pentingnya pemanfaatan limbah sayuran sebagai pupuk bokashi, karena setelah musim panen tiba petani membiarkan begitu saja sisa hasil panennya, bahkan sebagian dibuang ke aliran sungai tanpa pemanfaatan. Fakta di lapangan menunjukkan bahwa petani menganggap pupuk kompos sama dengan pupuk kandang. Padahal terdapat perbedaan bahan baku yang digunakan untuk membuatnya. Selain itu, petani tidak terlalu banyak mengetahui bahwa limbah sayuran selain dibuat menjadi pupuk kompos padat, limbah sayuran juga bisa dimanfaatkan sebagai pupuk kompos cair untuk pemupukan susulan sehingga mampu mengurangi 
penggunaan pupuk kimia. Pembuatannya pun tidak membutuhkan tempat yang luas.

Pada indikator sikap, sebanyak 11 responden $(36,7 \%)$ termasuk ke dalam kategori rendah, 19 responden $(63,3 \%)$ sedang, dan tidak ada responden yang memiliki nilai tinggi. Petani memberikan respon positif terkait dengan pemanfaatan limbah sayur sebagai pupuk kompos. Bahkan menurut petani, permintaan akan pupuk kompos sangat tinggi. Petani menyadari bahwa pupuk kompos berfungsi untuk memperbaiki sifat fisik, kimia, dan biologi tanah. Petani juga menyadari dengan membuat pupuk kompos sendiri akan menekan biaya produksi. Namun, mereka tetap menggunakan pupuk kimia sebagai pupuk susulan karena pupuk kimia memiliki reaksi yang lebih cepat sehingga hasilnya dapat dilihat dalam hitungan hari. Temuan di lapangan juga menunjukkan beberapa petani mencampurkan pupuk organik cair dengan pupuk kimia sebagai pupuk susulan. Hal ini karena kombinasi kedua pupuk ini akan berdampak baik bagi tanaman. Sesuai dengan pendapat Quansha (2010) dalam (Sulistyowati, 2018), yang menyatakan bahwa kombinasi antara pupuk anorganik dengan organik umumnya lebih meningkatkan pertumbuhan karena bahan organik dapat memperbaiki kondisi tanah sehingga unsur hara lebih tersedia untuk tanaman. Selain itu, sebagian besar petani lebih memilih langkah praktis, yaitu membeli pupuk kompos yang sudah jadi. Tapi, masih ada petani yang melakukan pembuatan pupuk kompos sendiri untuk lahan usahataninya, khususnya kompos cair. Selain itu, proses yang panjang dalam membuat pupuk kompos menyebabkan sebagian petani enggan untuk menerapkannya. Hal ini selaras dengan penelitian (Supaporn et al., 2013) yang mengatakan bahwa kesulitan dan proses yang panjang dalam membuat kompos dapat dianggap sebagai faktor kunci yang memiliki hubungan dengan daya serap petani terhadap inovasi pembuatan pupuk kompos.

Pada indikator keterampilan, sebanyak 16 responden $(53,3 \%)$ termasuk ke dalam kategori rendah, 10 responden $(33,3 \%)$ sedang, dan 4 responden $(13,3 \%)$ tinggi. Hasil ini berbeda dengan penelitian Redono, (2016) yang mengungkapkan bahwa secara keseluruhan tingkat keterampilan termasuk dalam kategori sedang dengan persentase $40 \%$. Perbedaan ini dapat terjadi karena perbedaan wilayah pengkajian juga sampel yang diteliti. Rendahnya keterampilan petani dikarenakan petani sudah jarang mengolah pupuk kompos sendiri. Berdasarkan hasil wawancara, terakhir kali rumah kompos digunakan adalah 2 tahun yang lalu sehingga petani sudah lama tidak melakukan kegiatan pembuatan pupuk kompos. Kebanyakan petani sekarang hanya menyimpan dedaunan sayuran sisa panen di pinggir kebun mereka dan membiarkannya membusuk secara alami tanpa ada perlakuan lebih lanjut. Hal ini terjadi karena kurangnya bahan baku kotoran ternak untuk membuat pupuk kompos, terutama kompos padat. Padahal untuk membuat kompos cair petani tidak terlalu membutuhkan kotoran ternak. Penyuluh pun pernah menyampaikan materi terkait pembuatan pupuk kompos cair dari limbah sayuran, namun sebagian besar petani tidak mempraktekkan ilmu yang telah diberikan oleh penyuluh. 
Indikator - Indikator yang Berhubungan dengan Respon Petani dalam Pemanfaatan Limbah Organik Sayuran Sebagai Pupuk Kompos Pada Komoditas Sayuran

Dalam pengkajian ini, didapatkan hasil analisis dari hubungan setiap indikator pada variabel $\mathrm{X} 1$ dan X2 dengan respon petani. Adapun hasil dari analisis tersebut dapat dilihat pada Tabel 5.

Tabel 5

Hubungan Indikator Variabel XI dan X2 dengan Respon Petani

\begin{tabular}{lcc}
\hline \multicolumn{1}{c}{ Indikator } & Korelasi & Sig. \\
\hline Umur & 0,245 & 0,192 \\
\hline $\begin{array}{l}\text { Tingkat } \\
\text { Pendidikan }\end{array}$ & 0,828 & 0,000 \\
Formal & & \\
\hline $\begin{array}{l}\text { Lama } \\
\text { Berusahatani }\end{array}$ & $-0,506$ & 0,004 \\
\hline $\begin{array}{l}\text { Luas Lahan } \\
\text { Garapan }\end{array}$ & 0,233 & 0,216 \\
\hline $\begin{array}{l}\text { Kegiatan } \\
\text { Penyuluhan }\end{array}$ & 0,558 & 0,001 \\
\hline $\begin{array}{l}\text { Ketersediaan } \\
\text { Sarana dan } \\
\text { Prasarana }\end{array}$ & 0,029 & 0,880 \\
\hline Akses Informasi & 0,112 & 0,557 \\
\hline $\begin{array}{l}\text { Dukungan } \\
\text { Poktan }\end{array}$ & 0,050 & 0,793 \\
\hline Sumber: Data & & \\
\hline
\end{tabular}

Sumber: Data diolah Penulis (2020)

Dalam Tabel 5, indikator yang memiliki hubungan nyata dengan respon petani adalah tingkat pendidikan formal, lama berusahatani, dan kegiatan penyuluhan

Koefisien korelasi antara tingkat pendidikan formal dengan respon petani adalah sebesar 0,828 dengan nilai signifikansi $0,000<0,005$. Artinya, terdapat hubungan nyata yang sangat kuat antara tingkat pendidikan formal dengan respon petani. Nilai yang positif menunjukkan hubungan yang terjadi adalah hubungan searah.
Berdasarkan pengamatan di lapangan, semakin tinggi pendidikan responden maka respon petani pun semakin meningkat, terutama pada indikator pengetahuan dan keterampilan. Hal ini selaras dengan penelitian Nurhafni (2014) yang menyatakan bahwa petani yang memiliki pendidikan yang tinggi akan berfikir lebih maju dan lebih mudah mengambil keputusan. Tingkat pendidikan merupakan faktor penunjang dalam penyerapan teknologi oleh petani. Menurut Soekartawi (2005) dalam Heriyadi et al., (2016) secara umum petani yang berpendidikan tinggi akan lebih baik cara berpikirnya, sehingga memungkinkan mereka bertindak lebih rasional dalam mengelola usahataninya. Selain itu, menurut Charina et al., (2018), Tingkat pendidikan seorang petani berhubungan dengan pengetahuan dan kemampuan petani dalam menganalisis berbagai informasi sebelum menerapkan inovasi baru.

Indikator yang berhubungan selanjutnya adalah lama berusahatani. Pada indikator ini, didapatkan hasil nilai koefisien korelasi lama berusahatani dengan respon adalah 0,506 , artinya hubungan antara lama berusahatani dengan respon petani sedang. Angka negatif menandakan hubungan yang terjadi adalah berlawanan arah, artinya jika terjadi peningkatan pada indikator lama berusahatani, maka respon petani semakin menurun. Nilai signifikansi pada hubungan ini adalah 0,004 < 0,005 yang artinya hubungan yang terjadi adalah nyata.

Berdasarkan hasil wawancara mendalam pada responden, petani yang memiliki pengalaman lama dalam berusaha tani, akan menimbang-nimbang terlebih dahulu 
terkait teknologi baru. Mereka memiliki tingkat pengetahuan dan keterampilan yang cukup tinggi, namun dari segi sikap mereka lebih cenderung menolak. Karena semakin berpengalaman maka petani akan semakin memikirkan kondisi usahataninya. Mereka akan berfikir apakah dengan membuat pupuk kompos dari limbah sayuran dapat menekan biaya produksi dan meningkatkan hasil panen. Hal ini selaras dengan pendapat Sutarto (2008) dalam penelitian Dewi et al., (2018) yang mengungkapkan bahwa semakin lama pengalaman bertani dari seorang petani maka dapat dikatakan petani tersebut sudah mampu menghadapi situasi atau halhal yang terjadi dalam kegiatan bertani. Namun berbeda dengan pendapat Rukka et al., (2013) yang mengatakan bahwa semakin lama pengalaman berusahatani maka tingkat mengadopsi suatu teknologi akan semakin tinggi. Perbedaan ini dapat terjadi karena perbedaan wilayah, responden, dan juga jumlah sampel yang diteliti.

Terakhir, indikator yang memiliki hubungan nyata dengan respon petani adalah kegiatan penyuluhan. Pada indikator ini, didapatkan hasil nilai koefisien korelasi kegiatan penyuluhan dengan respon adalah 0,558, artinya hubungan antara kegiatan penyuluhan dengan respon petani adalah sedang. Angka positif menandakan hubungan yang terjadi adalah searah, artinya jika terjadi peningkatan pada indikator kegiatan penyuluhan, maka respon petani semakin meningkat. Nilai signifikansi pada hubungan ini adalah 0,001 < 0,005 yang artinya hubungan yang terjadi adalah nyata.
Semakin sering diadakan penyuluhan, maka respon petani berupa pengetahuan, sikap dan keterampilannya akan meningkat. Hal ini sejalan dengan penelitian Anggini et al., (2019) yang menyatakan bahwa semakin tinggi intensitas kegiatan penyuluhan, kesesuaian materi, media serta metode penyuluhan pada petani maka perilakunya dalam pemanfaatan limbah sayuran sebagai pupuk bokashi (kompos) semakin tinggi. Hal ini semakin diperkuat oleh pendapat Setiana (2005) dalam Anggini et al., (2019) yang menyatakan bahwa penyuluhan merupakan sumber informasi yang berperan dalam menjembatani antara pengetahuan dan teknologi selalu berkembang dengan kegiatan usahatani yang dijalankan oleh petani. Selain itu, Singh et al., (2015) juga menyatakan bahwa kegiatan penyuluhan akan membantu petani dalam memperoleh informasi terbaru terkait aktivitas usahatani dan mendorong petani untuk menerapkan sebuah inovasi baru.

Fakta di lapangan ditemukan bahwa kegiatan penyuluhan secara formal dan berkelompok sudah jarang dilakukan atau tidak rutin. Namun penyuluhan dilakukan secara individu atau anjangsana baik ke rumah petani ataupun ke kebun petani. Di dalam kelompoktani pun jarang dilakukan pertemuan rutinan. Hal ini berbanding terbalik dengan penelitian Anwarudin \& Dayat (2019), yang menyatakan bahwa kegiatan penyuluhan rutin dilakukan secara mandiri dalam kelompok tani. Antara anggota kelompok tani juga saling memberikan umpan balik dan solusi berdasarkan pengalaman masingmasing anggota. Hal ini dapat dimaklumi karena Anwarudin \& Dayat melakukan penelitian di 
Kabupaten Bogor sedangkan penulis melakukan penelitian di Kecamatan Lembang Kabupaten Bandung Barat.

Indikator yang Harus Ditingkatkan untuk Memacu Respon Petani dalam Pemanfaatan Limbah Organik Sayur sebagai Pupuk Kompos

Berdasarkan hasil analisis diatas, perlu dilakukan analisis untuk mengetahui indikator apa saja yang harus ditingkatkan untuk memacu respon petani dalam pemanfaatan limbah organik sayur sebagai pupuk kompos. Salah satu cara untuk meningkatkan respon petani adalah dengan diadakannya penyuluhan. Namun penyuluhan yang dilaksanakan harus didasarkan hasil analisis terhadap indikator-indikator pada respon yang memiliki nilai rendah. Sesuai dengan pendapat Mardikanto dalam Anggini et al., (2019) kegiatan penyuluhan bukanlah kegiatan bersifat mendadak atau insidental, melainkan harus terencana atau telah direncanakan sebelumnya. Selanjutnya, sesuai dengan prinsipprinsipnya setiap kegiatan penyuluhan harus mengacu kepada kebutuhan yang (sedang) dirasakan klien-nya, baik yang berkaitan dengan kebutuhan kini, dan kebutuhan masa mendatang (jangka pendek, menengah dan jangka panjang).

Untuk mengetahui indikator mana yang harus ditingkatkan, penulis menggunakan analisis Kendall's $W$. Adapun hasil dari analisis tersebut dapat dilihat pada Tabel 6 .

\section{Tabel 6}

Analisis Kendall's W pada Variabel Respon

\begin{tabular}{ccc}
\hline Indikator & Mean & Prioritas \\
\hline Pengetahuan & 2,42 & III \\
Sikap & 1,83 & II \\
Keterampilan & 1,75 & I \\
\hline
\end{tabular}

Sumber: Data diolah Penulis (2020)

Berdasarkan hasil analisis diatas, indikator keterampilan mendapatkan mean rank yang paling kecil, yaitu 1,75. Maka, penyuluhan difokuskan kepada peningkatan keterampilan petani dalam memanfaatkan limbah organik sayur sebagai pupuk kompos. Hasil ini selaras dengan penelitian Anggini et al., (2019) yang menunjukkan bahwa keterampilan petani belum begitu bagus dalam memanfaatkan limbah sayuran sebagai pupuk bokashi. Selanjutnya, dilakukan analisis Kendall's $W$ pada parameter di dalam indikator keterampilan. Adapun hasil dari analisis tersebut dapat dilihat pada Tabel 7.

Tabel 7

Analisis Kendall's W pada Indikator Keterampilan

\begin{tabular}{ccc}
\hline Parameter & Mean & Prioritas \\
\hline Menyiapkan Alat & 3,65 & III \\
dan Bahan & 2,87 & I \\
Membuat Pupuk & 25 & IV \\
Mengidentifikasi & 3,95 & V \\
Pupuk Matang & & \\
Mengemas Pupuk & 4,02 & II \\
Mengaplikasikan & 3,43 & \\
Pupuk & & VII \\
Melakukan & 5,58 & Pencatatan \\
Menyimpan Pupuk & 4,50 & VI
\end{tabular}

Sumber: Data diolah Penulis (2020)

Berdasarkan hasil analisis Kendall's $W$ pada indikator keterampilan, parameter yang mendapatkan mean rank paling rendah yang pertama adalah parameter membuat pupuk dan yang kedua adalah parameter mengaplikasikan pupuk. Maka dari itu, perlu dilakukan tindakan untuk meningkatkan respon petani dalam pemanfaatan limbah organik sayuran.

Salah satu hal yang bisa dilakukan untuk meningkatkan keterampilan petani adalah dengan melakukan kegiatan penyuluhan. Seperti yang 
sudah dibuktikan Pradiana et al., (2020) dalam penelitiannya membuktikan keterampilan petani mengenai pembuatan pupuk bokashi mengalami peningkatan setelah diadakan kegiatan penyuluhan. Rerata nilai keterampilan petani pada tes awal adalah 64,75 dan rerata nilai tes akhir 85,75 sehingga peningkatan nilai angka keterampilan petani tentang pembuatan pupuk bokashi adalah 21,00. Hal ini juga selaras dengan penelitian Pratiwi \& Sudrajat (2012) yang menyatakan bahwa petani yang pernah mengikuti penyuluhan akan memiliki perilaku yang lebih baik atau yang berwawasan lingkungan dibanding dengan petani yang tidak pernah mengikuti penyuluhan pertanian.

\section{Kesimpulan}

Respon petani dalam pemanfaatan limbah organik sayuran sebagai pupuk kompos pada komoditas sayuran secara keseluruhan termasuk kedalam kategori sedang dengan persentase petani 53,3\%. Lalu, terdapat hubungan searah yang sangat kuat dan nyata pada indikator tingkat pendidikan formal dengan nilai korelasi 0,828, kemudian terdapat hubungan berlawanan yang sedang dan nyata pada indikator lama berusahatani dengan nilai korelasi 0,506, dan terdapat hubungan searah yang sedang dan nyata pada indikator kegiatan penyuluhan dengan nilai 0,558 . Selanjutnya, indikator yang harus ditingkatkan berdasarkan hasil analisis Kendall's W adalah indikator keterampilan. Adapun parameter yang harus ditingkatkan adalah cara membuat pupuk kompos dan cara mengaplikasikan pupuk kompos. Selanjutnya dilakukan penyuluhan untuk meningkatkan respon petani.
Adapun saran yang dapat disampaikan berdasarkan hasil pengkajian ini adalah sebagai berikut: (1) Diharapkan kegiatan penyuluhan dapat lebih digiatkan lagi untuk meningkatkan respon petani, khususnya dalam pemanfaatan limbah sayuran sebagai pupuk kompos. (2) Perlunya pendampingan oleh penyuluh untuk memanfaatkan sarana dan prasarana yang sudah ada sehingga kegiatan pembuatan pupuk kompos dapat berjalan kembali. (3) Untuk penelitian selanjutnya, diharapkan dapat dilakukan lebih baik lagi dengan mengkaji variabel dan indikator baru dan responden yang lebih banyak agar hasil yang didapatkan dapat lebih baik dari sebelumnya.

\section{Ucapan Terimakasih}

Terimakasih kepada Dosen Pembimbing 1 dan 2 yang telah membimbing peneliti sampai saat ini. Ucapan terimakasih jugap peneliti sampaikan kepada kedua orang tua yang selalu mendoakan kelancaran penelitian ini, juga kepada temanteman yang senantiasa bertukar ilmu untuk mendukung penelitian ini.

\section{Daftar Pustaka}

Alam, N. 2010. Faktor-Faktor yang Mempengaruhi Petani Kakao dalam Adopsi Inovasi Teknologi Sistem Usahatani Intensifikasi dan Diversifikasi. Institut Pertanian Bogor.

Anggini, D., Hartono, R., \& Anwarudin, O. 2019. Perilaku Petani dalam Pemanfaatan Limbah Sayuran Sebagai Pupuk Bokashi pada Tanaman Sawi Putih. Jurnal Triton, 10(1), 99115. 
Anwarudin, O., \& Dayat. 2019. The Effect of Farmer Participation in Agricultural Extension on Agribusiness Sustainability in Bogor, Indonesia. International Journal of Multicultural and Multireligious Understanding, 6(3), 1061-1072.

Badan Pusat Statistik Indonesia. 2018. Kecamatan Cisarua dalam Angka. Jakarta.

Balai Penyuluhan Pertanian Kec. Cisarua. 2018. Programa Penyuluhan Kecamatan Cisarua Kabupaten Bandung Barat. Bandung Barat.

BPS Kabupaten Bandung Barat. 2016. Kabupaten Bandung Barat dalam Angka (Bandung Barat in Figures).

Charina, A., Kusumo, R. A. B., Sadeli, A. H., \& Deliana, Y. 2018. Faktor-faktor yang Mempengaruhi Petani dalam Menerapkan Standar Operasional Prosedur (SOP) Sistem Pertanian Organik di Kabupaten Bandung Barat. Jurnal Penyuluhan, 14(1).

Dewi, I. N., Awang, S. A., Andayani, W., \& Suryanto, P. 2018. Karakteristik Petani dan Kontribusi Hutan Kemasyarakatan (HKm) Terhadap Pendapatan Petani di Kulon Progo. Jurnal Ilmu Kehutanan, 12(2 2013), 86-98. https://jurnal.ugm.ac.id/jikfkt

Heriyadi, Billah, M. T., \& Dayat. 2016. Tingkat Partisipasi Anggota Kelompoktani Dalam Penyusunan Rencana Definitif Kelompok dan Rencana
Definitif Kebutuhan Kelompok Padi Sawah (Oryza sativa L.) Di Desa Cibeuteung Muara Kecamatan Ciseeng Kabupaten Bogor. Jurnal Penyuluhan Pertanian, 67-81.

Manatar, M. P., Laoh, E. H., \& Mandei, J. R. 2017. Pengaruh Status Penguasaan Lahan Terhadap Pendapatan Petani Padi di Desa Tumani, Kecamatan Maesaan , Kabupaten Minahasa Selatan. Jurnal Agro-SosioEkonomi, 13(1), 55-64.

Manyamsari, I., \& Mujiburrahmad. 2014. Karakteristik Petani dan Hubungannya dengan Kompetensi Petani Lahan Sempit. Jurnal Agrisep, 15(2), 58-74.

Nurhafni. 2014. Hubungan Karakteristik Petani dengan Partisipasi Petani Dalam Melaksanakan Fungsi Kelompoktani di Kecamatan Idi Tunong Kabupaten Aceh Timur. Medan.

Pradiana, W., Sulistya, D., \& Setiawati, $\quad$ A. 2020. Pengembangan Agribisnis Padi Sawah melalui Pemberdayaan Kelompok Tani. Jurnal Penyuluhan Pertanian, 2(2), 171-182.

Pratiwi, E. R., \& Sudrajat. 2012. Perilaku Petani dalam Mengelola Lahan Pertanian di Kawasan Rawan Bencana Longsor. Jurnal Bumi Indonesia, 1(3), 355-362.

Putri, C. A., Anwarudin, O., \& Sulistyowati, D. 2019. 
Partisipasi Petani Dalam

Kegiatan Penyuluhan dan

Aadopsi Kabupaten Garut.

Jurnal Agribisnis Terpadu, 103119.

Redono, C. 2016. Respon Petani Terhadap Penggunaan Pupuk Organik Pada Tanaman Padi Sawah di Kelurahan Bokoharjo Kecamatan Prambanan Kabupaten Sleman. Jurnal Agrica Ekstensia, 10(1), 29-36.

Rinanto, Y., Sajidan, \& Fatmawati, U. 2015. Pemanfaatan Limbah Sisa Hasil Panen Petani Sayuran di Boyolali sebagai Bahan Baku Pembuatan Pupuk Cair Organik menuju Pertanian Ramah Lingkungan. Seminar Nasional Konservasi Dan Pemanfaatan Sumber Daya Alam, 231-236.

Rukka, Hermaya, \& Wahhab, A. 2013. Faktor yang mempengaruhi motivasi petani dalam pelaksanaan kegiatan P2BN di Kecamatan Barru Kabupaten Barru. Jurnal Agrisistem.

Ruyadi, I., Winoto, Y., \& Komariah, N. 2017. Media Komunikasi Dan Informasi Dalam Menunjang Kegiatan Penyuluhan Pertanian. Jurnal Kajian Informasi Dan Perpustakaan, 5(1), 37.

Singh, M., Maharjan, K. L., \& Maskey, B. 2015. Factors Impacting Adoption of Organic Farming in Chitwan District of Nepal. Asian Journal of Agriculture and Rural Development, 5(1), 1-12.

Sulistyowati, D. 2018. Aplikasi
Formulasi Pupuk Serta

Penambahan Kompos Jerami Terhadap Produksi Cabai Merah ( Capsicum annuum L . ). Jurnal Agroekoteknologi Dan Agribisnis, 1(2), 33-43.

Supaporn, P., Kobayashi, T., \& Supawadee, C. 2013. Factors Affecting Farmers' Decisions on Utilization of Rice Straw Compost in Northeastern Thailand. Journal of Agriculture and Rural Development in the Tropics and Subtropics, 114(1), 21-27.

Viaene, J., Van Lancker, J., Vandecasteele, B., Willekens, K., Bijttebier, J., Ruysschaert, G., De Neve, S., \& Reubens, B. 2016. Opportunities and Barriers to On-farm Composting and Compost Application: A Case Study from Northwestern Europe. Waste Management, 48(October), 181-192.

Wahyono, S. 2011. Pengolahan Sampah Organik dan Aspek Sanitasi. Jurnal Teknologi Lingkungan, 2(2), 113-118. http://kelair.bppt.go.id/

Wardana, I. G. N. W., Tariningsih, D., \& Lestari, P. F. K. 2017. Pengetahuan dan Keterampilan Petani Terhadap Pupuk Organik pada Usahatani Padi Sawah. Jurnal Agrimeta, 7(13), 94-104. 